\title{
The Impact of Entrepreneurship on Engineering Education
}

\author{
Majed Jarrar and Hanan Anis \\ University of Ottawa \\ mjarrar@uottawa.ca, hanis@uottawa.ca
}

\begin{abstract}
Engineering schools are integrating entrepreneurship within their curriculum in order to equip their students with the capacity to adapt quickly to technological innovation. The University of Ottawa has developed an entrepreneurship course that is open to all engineering students, and aims to provide them with a hands-on approach to starting and growing a technology start-up. This paper is centred on assessing the students who took this course. The results of the survey analyze the impact entrepreneurship has had on their engineering skillset. This skillset reflects the graduate attributes that the Canadian Engineering Accreditation Board (CEAB) expects engineering students to develop. We will observe whether this impact has changed since the inception of this course in 2012 and throughout 5 course cycles. Using the survey results as well as the direct observation during those semesters, we present our analysis on how these outcomes can be replicated in other environments.
\end{abstract}

Keywords: entrepreneurial education, engineering education, technology entrepreneurship, engineeringentrepreneurs, Canadian engineering accreditation board, entrepreneurial skillset, engineering course.

\section{INTRODUCTION}

Research on entrepreneurship and engineering education is not a new thing, it goes to more than a century [1]. However, it was after the dot com bubble burst in the $21^{\text {st }}$ century that entrepreneurship became a mainstream research topic in engineering education. The idea of integrating entrepreneurship with engineering education seems to pick up whenever there is a volatile or gloomy forecast of the economy. That is why it is currently one of the fastest growing undergraduate subjects in American universities, having more than quadrupled in the last 30 years [2].

We have developed a course at the University of Ottawa for teaching entrepreneurship to engineering students. The course, named Technology Entrepreneurship for Engineers and Computer Scientists, is one semester long, normal credit load and is open to all undergraduate and graduate engineering students. We have seen the students improve a number of skills when they take the course. For that reason, we have created a survey as a self-assessment tool to collect the students' perception on how they think entrepreneurship has improved their engineering education.

In this paper, we present how entrepreneurial education in engineering schools improve, not only good entrepreneurial skillset, but also the core engineering skillset of engineering students. In section 2, we briefly summarize the background of the research and the graduate attributes which Canadian Engineering Accreditation Board (CEAB) expects engineering students to develop. In section 3, we present the entrepreneurship course we have developed for engineering students at the University of Ottawa. In section 4, we explain the survey we have built to assess the course. Finally, we present our conclusive remarks and the steps ahead in section 5 .

\section{BACKGROUND}

Numerous case studies have indicated that entrepreneurship has created a positive impact on engineering students [3]-[15]. The majority of the researchers have strongly recommended expanding these programs to include more engineering students per university, and more universities around the world.

Our research began with looking at the generic impact of entrepreneurship on engineering education ( $1^{\text {st }}$ iteration). After that it was focused in the $2^{\text {nd }}$ iteration on the impact of entrepreneurial academic learning on engineering students. In the $3^{\text {rd }}$ iteration the focus moved away from full degree programs on entrepreneurship (such as certificates and minors) to only courses or modules within engineering. We reviewed those papers and we carefully picked the papers with the biggest impact in this area in the $4^{\text {th }}$ iteration. Table $\mathbf{1}$ shows the richness of literature in this topic and the four iterations.

Table 1: Literature of Entrepreneurship and Engineering Education

\begin{tabular}{|l|l|l|l|l|}
\hline \multicolumn{1}{|c|}{ Iteration } & $\mathbf{1}^{\text {st }}$ & $\mathbf{2}^{\text {nd }}$ & $\mathbf{3}^{\text {rd }}$ & $\mathbf{4}^{\text {th }}$ \\
\hline Scopus & 4,784 & 438 & 75 & 2 \\
\hline ProQuest & 147,510 & 101 & 33 & 10 \\
\hline IEEExplore & 1,920 & 39 & 18 & 9 \\
\hline JSTOR & 15,858 & 10 & 2 & 2 \\
\hline Total & 170,072 & 588 & 128 & $\mathbf{2 3}$ \\
\hline
\end{tabular}

There were a few papers that we studied that we ended up not selecting here due to the quality and/or relevance of their research. 


\subsection{Engineering Attributes}

According to the CEAB, every engineering student must develop a set of attributes during their undergraduate degree. Each one of these attributes have a definition and set of expectations set by the CEAB [16]. These attributes are:

1. Design

2. Investigation

3. Problem analysis

4. Life-long learning

5. Communication skills

6. Individual and team work

7. Economics and project management

8. Impact of engineering on society and the environment

9. A knowledge base for engineering

10. Use of engineering tools

11. Ethics and equity

12. Professionalism

Of these twelve, we believe that integrating entrepreneurial education in engineering curricula can have a significant impact on improving at least the first seven of them.

We have used the definitions and expectations of these attributes set by the CEAB in evaluating the content of the entrepreneurship course we developed and in the survey we built. We have reasons to believe that some of these expectations are difficult or impossible to meet in a standard engineering course without an entrepreneurial element, for example: working with a multidisciplinary team on multidisciplinary problems, or the ability to incorporate business practices in the process of creating a solution.

\section{COURSE STRUCTURE}

While the course is open to all undergraduate and graduate engineering students at the University of Ottawa, most students take it in their final year so they can continue with their start-ups after graduation, find better opportunities, or benefit from the business training and networking to become stronger candidates for the jobs they seek. Many students who take the course enter (and win) entrepreneurial competitions held during the same semester or in the following year.

The course is one semester long and has been taught five times over the past three years, and we have used student feedback to improve the course structure in every cycle (or iteration), in order to increase teamwork effectiveness, maintain clear individual performance indicators and achieve balance between personal development and group collaboration.

\subsection{Individual Work}

Each student has a set of individual assignments which run throughout the course. Students are not discouraged from collaboration in discussion. However, their answers must be novel and represent their own thought process, particularly students within the same group.

3.1.1. Personal Development Action Plan. Students take two personality tests: The Myers-Briggs Type Indicator test and; The Discovery-Delivery Test [17]. Using the results of the two tests, students identify their strengths and weaknesses. Then, they write need statements explaining what skills they need to acquire or improve in order to become a better entrepreneur. Finally, they present their action plan detailing how they will execute their need statements.

3.1.2. Case Studies. Students are assigned 6 case studies from Harvard Business School throughout the term, and are given four open ended questions for each case study to answer. Since there is no textbook for the course, students are responsible for buying the case studies. Topics covered in the case studies usually include entrepreneurial characters, lean start-up, founders' dilemma, marketing, finance, legal issues, sustainability, exit strategies, etc.

3.1.3. Elevator Pitch. Soon after learning about entrepreneurship, each student is asked to record a 2-minute video pitch of themselves selling their own idea - and skills - to the rest of the class by the second week of the course. The pitch should include the problem they're trying to solve, the solution they're proposing, the target segment of customers, the expected income, the market size, and the competitive advantage. We encourage the students to use visual aids to display data while they're talking to maximize the efficiency of the short clip.

All students share their recordings on Blackboard; the digital platform for online classroom discussion, under one course blog, and they can view and comment on each other's videos. Students contact each other online and formulate teams of 4-6 students around one idea.

3.1.4. Exams. Students take a midterm in which they are given a case study and are expected to answer open ended questions. The students are given the case study a week in advance for the midterm exam. The final exam is a closed book exam.

\subsection{Group Work}

After the teams are formulated, each team is given their own group page on Blackboard which they can use for file sharing, online group-discussion, and submission of group work. The following are the five main learning outcomes of teamwork:

3.2.1. Opportunity Identification. Students learn about design thinking and integrating empathy with ideation, how 
to design a business model canvas (BMC) and how to put it to a stress-test. Each group develops three business model canvases: two to represent their own plan A and plan B and a third representing a real existing competitor. We found that students not only learn a great deal about the idea when they try to reverse engineer the BMC of an existing competitor, but it also help them draw their goals and resource management more realistically.

3.2.2. Customer Discovery. Groups go out to interview people whom they believe are potential customers. The semi-structured interviews are for two reasons: Groups get to learn more about these people, and they ask them for feedback on their current stage of the product. Customer discovery takes place as an iterative process throughout six weeks. On average, each group must have at least 4 significant interviews each week. This varies depending on the product and the customer segment. For example, a group that was working on a health related app had 10-15 different interviews per week while a group that was working on a drone were interviewing the same customer each week. According to the students who were surveyed after finishing the course, customer discovery was the most significant learning element of the course to them.

3.2.3. Launching Considerations. Groups get to know about essential pre-launch considerations such as the founders' dilemmas, equity, legal considerations, company valuation and how to register a new business federally and/or provincially. They develop a detailed 3-year financial projection backed market research, and write their own terms for a founders' agreement.

They also set a going-to-market strategy which includes their pricing strategy, sales channels, and how they are going to launch and advertise their products.

3.2.4. Prototyping. This is an important element that was significantly improved over the recent cycles of the course. Students are introduced early in the course to the resources found in our Makerspace and they use it as their prototyping hub. Knowing the available tools such as 3D printers, laser cutters, virtual reality platforms, Arduinos and Raspberry Pis can assist the students to think in more innovative ways when they are trying to solve a problem. Students use early prototypes in their customer interviews and present a final working product at the end of the course.

3.2.5. Evaluation. At the end of the semester, each group presents a 10-minute investor pitch and submits a final business plan. Also, each student submits a peer evaluation report in which they rate the contribution of each team member to every aspect of the group development. The peer assessment scores of all members in a group are averaged and student gets their own contribution coefficient. Each student gets the grades of group deliverables multiplied by their contribution coefficient.

CEEA16; Paper 098

Dalhousie University; June 19 - 22, 2016 -3 of $6-$

\section{SURVEY}

In the previous semesters we relied on casual comments and course evaluation surveys to get feedback from the students. We decided to develop a survey to evaluate how the students perceived the impact of the entrepreneurial learning they experienced in the course on their engineering education.

\subsection{Survey Questions}

To keep the survey within a reasonable time frame of 15 minutes, we decided to rely heavily on Likert scale questions. Nevertheless, if a student replies below neutral on a Strongly Agree to Strongly Disagree (SA-SD) scale question, an open ended question pops below asking for more details on why the experience was negative. If the student chooses to write an answer to that question, an additional question comes up asking if they could give an example of how this course could be taught differently in order to make that experience positive. The reason why we made these questions hidden by default and only show when prompted is because we didn't want the survey appear cluttered with so many questions and hence make people less willing to participate.

Table 2: Problem Analysis and Investigation Questions

\begin{tabular}{|l|l|}
\hline \multicolumn{1}{|c|}{ Questions } & Type \\
\hline $\begin{array}{l}\text { Learning about 'opportunity identification' has } \\
\text { improved my ability to define an engineering } \\
\text { problem }\end{array}$ & SA-SD \\
\hline $\begin{array}{l}\text { Working on a business model canvas made me } \\
\text { feel confident in formulating a solution plan }\end{array}$ & SA-SD \\
\hline $\begin{array}{l}\text { Having group deliverables that address one part } \\
\text { of the business at a time helped us break down } \\
\text { the problem to manageable tasks }\end{array}$ & SA-SD \\
\hline $\begin{array}{l}\text { Involving customers in the product } \\
\text { development leads to better solutions }\end{array}$ & SA-SD \\
\hline $\begin{array}{l}\text { Having a validation board is critical for the } \\
\text { problem analysis }\end{array}$ & SA-SD \\
\hline Identification of a problem & Compare \\
\hline Brainstorming and ideation & Compare \\
\hline Empathy with customer needs & Compare \\
\hline Methodology to formulate a solution plan & Compare \\
\hline Ability to carry out a solution model & Compare \\
\hline $\begin{array}{l}\text { Critically analyze the process we designed to } \\
\text { solve the problem }\end{array}$ & Compare \\
\hline
\end{tabular}

In addition to Table 2 above, which shows the questions on both problem analysis and investigation, Table 3 shows questions related to individual and teamwork, Table 4 shows communication questions, Table 5 shows questions 
pertaining to economics and project management, Table 6 shows design questions and Table 7 shows lifelong learning and self-efficacy questions.

Table 3: Individual and Teamwork Questions

\begin{tabular}{|l|l|}
\hline \multicolumn{1}{|c|}{ Questions } & \multicolumn{1}{|c|}{ Type } \\
\hline $\begin{array}{l}\text { I can now easily identify my strengths and what } \\
\text { needs improving }\end{array}$ & SA-SD \\
\hline $\begin{array}{l}\text { I know how to put an action plan to improve my } \\
\text { weaknesses }\end{array}$ & SA-SD \\
\hline $\begin{array}{l}\text { Forming a group with students from different } \\
\text { majors has enhanced my teamwork skills }\end{array}$ & SA-SD \\
\hline $\begin{array}{l}\text { I felt I could have worked more efficiently on } \\
\text { my own than with the group }\end{array}$ & SA-SD \\
\hline $\begin{array}{l}\text { The diverse perspectives we had in our } \\
\text { interdisciplinary group helped us develop a } \\
\text { better solution }\end{array}$ & SA-SD \\
\hline Set rules that increase effectiveness of the team & Compare \\
\hline Ability to follow a leader on certain task & Compare \\
\hline Collaborate with a team to solve one problem & Compare \\
\hline Foster a healthy team-based work environment & Compare \\
\hline Monitor the team's organizational structure & Compare \\
\hline
\end{tabular}

Table 4: Communication Questions

\begin{tabular}{|l|l|}
\hline \multicolumn{1}{|c|}{ Questions } & Type \\
\hline $\begin{array}{l}\text { Having to record a video sales pitch of myself } \\
\text { helped me gauge my communication skills }\end{array}$ & SA-SD \\
\hline $\begin{array}{l}\text { The course taught me that it is critical for an } \\
\text { engineer to know how to communicate directly } \\
\text { with customers }\end{array}$ & SA-SD \\
\hline $\begin{array}{l}\text { Conducting customer interviews for several } \\
\text { weeks improved my communication skills }\end{array}$ & SA-SD \\
\hline $\begin{array}{l}\text { Collaborating with my group members prepared } \\
\text { me for communication in real work } \\
\text { environments with a multi-disciplinary team }\end{array}$ & SA-SD \\
\hline $\begin{array}{l}\text { I think the course should focus more on product } \\
\text { development skills and less on communication } \\
\text { skills }\end{array}$ & SA-SD \\
\hline Working with multidisciplinary team & Compare \\
\hline Present a sales pitch to a public audience & Compare \\
\hline $\begin{array}{l}\text { Communicate effectively in writing and } \\
\text { verbally }\end{array}$ & Compare \\
\hline $\begin{array}{l}\text { Improve interview skills with rounds of } \\
\text { feedback }\end{array}$ & Compare \\
\hline $\begin{array}{l}\text { Switch between different modes of } \\
\text { communication }\end{array}$ & Compare \\
\hline
\end{tabular}

We put one reverse question on each page, such that a positive experience would mean an answer below neutral on a Likert scale. These questions are reversed to increase the confidence level of the collected responses. For example,

CEEA16; Paper 098

Dalhousie University; June 19 - 22, 2016

-4 of $6-$ someone who is clicking on the 'agree' in every question without reading the questions fully would be spotted using these reverse questions.

Table 5: Economics and Project Management Questions

\begin{tabular}{|l|l|}
\hline \multicolumn{1}{|c|}{ Questions } & \multicolumn{1}{|c|}{ Type } \\
\hline $\begin{array}{l}\text { I understand finances better after taking the } \\
\text { course }\end{array}$ & SA-SD \\
\hline $\begin{array}{l}\text { The course helped me understand basics of } \\
\text { legal, sales and marketing strategies }\end{array}$ & SA-SD \\
\hline $\begin{array}{l}\text { I wanted to learn less about economics and } \\
\text { project management }\end{array}$ & SA-SD \\
\hline $\begin{array}{l}\text { The course gave me confidence in setting a } \\
\text { good pricing strategy }\end{array}$ & SA-SD \\
\hline $\begin{array}{l}\text { Estimate the life-cycle financial projections } \\
\text { (earnings and costs) }\end{array}$ & Compare \\
\hline $\begin{array}{l}\text { Evaluate a financial plan against competitive } \\
\text { options }\end{array}$ & Compare \\
\hline Read and understand a financial statement & Compare \\
\hline Divide a complex problem to manageable tasks & Compare \\
\hline $\begin{array}{l}\text { Meet all necessary deadlines when developing a } \\
\text { product }\end{array}$ & Compare \\
\hline $\begin{array}{l}\text { Understand the limited nature of resources } \\
\text { when creating a solution }\end{array}$ & Compare \\
\hline
\end{tabular}

Table 6: Design Questions

\begin{tabular}{|l|l|}
\hline \multicolumn{1}{|c|}{ Questions } & \multicolumn{1}{|c|}{ Type } \\
\hline Better understand engineering design principles & SA-SD \\
\hline Gain experience with open-minded problems & SA-SD \\
\hline Generate creative ideas (e.g. brainstorming) & SA-SD \\
\hline Employ sustainability concepts into design & SA-SD \\
\hline Properly document the design process & SA-SD \\
\hline $\begin{array}{l}\text { Accrediting the previous work of others } \\
\text { properly }\end{array}$ & SA-SD \\
\hline Ability to evaluate your own design & SA-SD \\
\hline Ability to work in a group with different skills & SA-SD \\
\hline $\begin{array}{l}\text { Integrate economic aspects to the decision } \\
\text { making process }\end{array}$ & SA-SD \\
\hline $\begin{array}{l}\text { Learn to acquire and incorporate additional } \\
\text { knowledge on your own }\end{array}$ & SA-SD \\
\hline
\end{tabular}

In addition to the SA-SD questions, we used comparative questions, which are also 5-choice Likert scale. In comparative questions the respondents would answer how the course has contributed to the following in comparison with other engineering courses they have taken. Their choice would be ranging from "much more than other courses", to "similar", to "much less than other courses."

The survey concludes with two open ended questions: one for feedback about the survey and one if they have any additional comments. Many of the students who filled the 
survey have answered these last two questions and provided very useful feedback.

Table 7: Life Long Learning and Self Efficacy Questions

\begin{tabular}{|l|c|}
\hline \multicolumn{1}{|c|}{ Questions } & Type \\
\hline Your qualifications for the work & SA-SD \\
\hline Your confidence to apply (or start) & SA-SD \\
\hline Your skills at work & SA-SD \\
\hline Your learning on the job & SA-SD \\
\hline The quality of you work & SA-SD \\
\hline The efficiency of you work & SA-SD \\
\hline Your enjoyment of your work & SA-SD \\
\hline $\begin{array}{l}\text { My department addresses entrepreneurship } \\
\text { sufficiently }\end{array}$ & SA-SD \\
\hline $\begin{array}{l}\text { I retained what I learned in this course better } \\
\text { than other courses }\end{array}$ & SA-SD \\
\hline $\begin{array}{l}\text { I wish more engineering courses were like } \\
\text { this course }\end{array}$ & SA-SD \\
\hline Overall, I enjoyed this course & SA-SD \\
\hline
\end{tabular}

\subsection{Deploying the Survey}

The survey was submitted for ethics board approval. After one round of review the survey was approved. We began deployment with a small sample of former students whom we kept contact with after the course. They provided valuable feedback and we made minor adjustments. Then we created a survey collector per each cycle of the course and dispatched the survey collector through the Blackboard mailing list per each course.

The final version of the survey was dispatched in the first week of May 2016 and is expected to run for six weeks. There is a total of 350 students who took this course so far. We anticipate that student engagement from the more recent cohorts will be significantly higher than the earlier ones. Most of the students from the early cohorts have already graduated and less of them will be still regularly checking their university email address.

\section{CONCLUSION}

This paper presented the course Technology Entrepreneurship for Engineers and Computer Scientists as an example of entrepreneurial education in engineering schools. The course aims at equipping engineering students with an entrepreneurial mindset and skillset, both of which are much needed in the marketplace today. More than 350 students have taken the course so far and formed over 60 start-ups, many have entered into entrepreneurial competitions and some spun off to real companies.

We designed a survey to collect the students' perception

CEEA16; Paper 098

Dalhousie University; June 19 - 22, 2016

-5 of $6-$ on the impact of entrepreneurial education on their engineering education. Specifically, we wanted to know how entrepreneurship has impacted the attributes of: Design, investigation, problem analysis, life-long learning, communication, individual and team work, economics and project management. The survey was deployed recently and will be running for four weeks. So far after one week of deployment we have received responses from $10 \%$ of the total sample frame. Our initial findings show that the majority of students agree that teaching entrepreneurship significantly helps improve the core engineering skillset of engineering students. Many have written additional comments and indicated that the course has substantially improved their skills and contributed to their careers. Nevertheless, this small sample size should grow in the next few weeks.

\subsection{Further Steps}

We have designed the survey as a tool to be used beyond this course, ensuring that the terminology and questions are objective and appropriate to changing contexts. Our next step is to deploy the survey to other entrepreneurial courses offered to engineering students at the University of Ottawa and beyond. This will help us gather more data on how these courses are impacting engineering students.

5.1.1. Pre-course survey. We're currently also working on a pre-course survey to be administered to engineering students when they first enroll in the entrepreneurial course. This way we can have a more accurate measure of the impact the course has specifically added to students' skillset.

5.1.2. Tools. A survey is a self-reporting tool that is beneficial but has limitations. We are exploring with a number of assessment methods beyond self-reporting through which we can collect multi-dimensional data from the students, in order to make a stronger case for creating entrepreneurial courses and modules in more engineering schools.

\section{Acknowledgements}

We would like to thank NSERC for their funding and support for this project. We would also like to thank fellow professors, university administrators, researchers, students and alumni of uOttawa for their support; without them this research would not have been possible.

\section{References}

W. B. Carlson, Academic Entrepreneurship and Engineering Education: Dugald C. Jackson and the MIT-GE Cooperative Engineering Course, 19071932, vol. 29, no. 3. Chicago and London: 
University of Chicago Press, 1991.

[2] T. Byers, T. Seelig, S. Sheppard, and P. Weilerstein, "Entrepreneurship: Its Role in Engineering Education,” Bridg., no. Summer, 2013.

[3] D. F. D. F. Barbe, S. A. S. A. Magids, and K. S. K. S. Thornton, "Holistic approach for technology entrepreneurship education in engineering," in 33rd Annual Frontiers in Education, 2003. FIE 2003., 2003, vol. 1, pp. T2D_1-T2D_6.

[4] S. Celis Guzman, "How intellectual movements among external and internal actors shape the college curriculum: the case of entrepreneurship education in engineering," University of Michigan, Ann Arbor, 2015.

[5] P. G. Crawford, J. D. Broer, and W. C. Bastiaansen, “Engineering Education on the 'Fuzzy' Front End: A High-Technology Entrepreneurship Model,” Eur. J. Eng. Educ., vol. 31, no. 2, pp. 145-153, May 2006.

[6] C. J. Creed, E. M. Suuberg, and G. P. Crawford, "Engineering entrepreneurship: An example of a paradigm shift in engineering education,” Journal of Engineering Education, vol. 91, no. 2. pp. 185195, 2002.

[7] S. Doboli, G. L. Kamberova, J. Impagliazzo, X. Fu, and E. H. Currie, "A model of entrepreneurship education for computer science and computer engineering students," in 2010 IEEE Frontiers in Education Conference (FIE), 2010, pp. T4D-1T4D-6.

[8] N. Duval-Couetil, "Engineering students and entrepreneurship education: Involvement, attitudes and outcomes,” Int. J. Eng. Educ., vol. 28, no. 2, pp. 425-435, 2012.

[9] D. T. Gerba, "Impact of entrepreneurship education on entrepreneurial intentions of business and engineering students in Ethiopia,” African J. Econ. Manag. Stud., vol. 3, no. 2, pp. 258-277, 2012.

[10] F. Hassan, H. LeBlanc, and K. Al-Olimat,
"Inculcating an entrepreneurial mindset in engineering education: Project approach,” in 2013 IEEE Frontiers in Education Conference (FIE), 2013, pp. 121-126.

[11] D. Ilea, "Integrating entrepreneurship education into electrical engineering curriculum,” in IEEE 2nd Integrated STEM Education Conference, 2012, pp. $1-4$.

[12] S. Luryi, W. Tang, N. Lifshit, G. Wolf, S. Doboli, J. A. Betz, P. Maritato, and Y. Shamash, "Entrepreneurship in engineering education," in 2007 37th annual frontiers in education conference - global engineering: knowledge without borders, opportunities without passports, 2007, pp. T2E-10T2E-15.

[13] A. Mathew, V. Pangracious, A. Varghese, A. Thomas, D. Mathew, and J. George, "PROJECT HAWK: An innovative introduction of practical learning and entrepreneurship in engineering education," in 2012 2nd Interdisciplinary Engineering Design Education Conference (IEDEC), 2012, pp. 34-40.

[14] M. Polczynski and S. Jaskolski, "Entrepreneurial Engineering Education," in National Collegiate Inventors and Innovators Alliance. Proceedings of the ... Annual Conference, 2005, pp. 93-101.

[15] M. Salama, "Case Study: Complementing the Engineering Education with Entrepreneurial Program at Shoubra Faculty of Engineering, Bahna University, Egypt," in 2010 IEEE Transforming Engineering Education: Creating Interdisciplinary Skills for Complex Global Environments, 2010, pp. 1-8.

[16] Canadian Engineering Accreditation Board, “Graduate Attributes,” 2016.

[17] J. H. Dyer, H. B. Gregersen, and C. M. Christensen, “The Innovator's DNA," Harv. Bus. Rev., vol. 87, no. 12, pp. 1-9, 2009. 